\title{
一軸圧縮荷重下での岩石のクリープ特性*
}

\author{
福 井 勝 則 $^{1}$ 大久保誠 介 $^{2}$ 西松 裕 - 3
}

[UDC 624.131 .37$]$

\section{Creep Behavior of Rock under Uniaxial Compression}

by Katsunori FUKUI ${ }^{1}$, Seisuke OKUBO $^{2}$ and Yuichi NISHIMATSU ${ }^{3}$

Uniaxial compression creep tests were conducted under comparatively high stress level $(90 \sim 95 \%$ of strength) on Inada-granite, Tako-sandstone, cement-mortar and Akiyoshi-marble. The following results are obtained;

1) In all samples, the primary creep follows the logarithmic creep law.

2) The secondary creep where strain rate is nearly constant is apparent only for cement-mortar. For other samples, the strain rate continuously decreases at first, and increases after taking its minimum.

3) For Tako-sandstone and Akiyoshi marble, the value of creep strain at the minimum strain rate is nearly equal to half of the width of the complete-stress-strain curve cross-sectioned at corresponding creep stress. In case of granite, the creep strain at minimum strain rate is rather small, whereas, in case of cement-mortar nearly double of the width.

4) Strain rate at an arbitrary time in tertiary creep is inversely proportional to the residual time up to final failure. If this law is applied to rock mass, the failure of underground constructions may be predicted.

5) Except cement-mortar, the creep strain just before final failure (1 sec before failure) is nearly equal to the cross-sectional width of the complete-stress-strain curve. In case of cement-mortar, the creep strain just before final failure is as much larger than the width.

$1 \sim 3$. Faculty of Engineering, The University of Tokyo.

1. Graduate Student 2. Assoc. Prof., Dr. $\quad 3$. Prof., Dr.

\section{1. はじめに}

クリープ試験は, 実験方法が比較的簡単なので, 岩石の時間依 存性挙動を調べるために，古くから行なわれている ${ }^{1) \sim 7)}$ 。例えば Parsons ら ${ }^{1)}$ は, 20 種類の岩石に対して破壊荷重の $50 \%$ 程度でク リープ試験を行ない, 大部分の岩石において, 対数クリープ則に 近い関係が見られたとしている。Kranz ら ${ }^{2)}$ は, 三次クリープ開 始点の非弾性体積歪を測定し，同一岩種であれば, クリープ応力

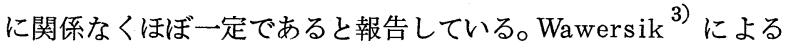
と, クリープ挙動は, 完全応力一歪線図と深くかかわっており, クリープ変形が進行し, 強度破壞点以降の応力ー歪曲線の位置ま で歪が蓄積すると三次クリープになる。ここで挙げた報告以外に も多くの報告がなされているが，そのほとんどは一次クリープ， 二次クリープ，あるいは三次クリープ開始点についてであり，三

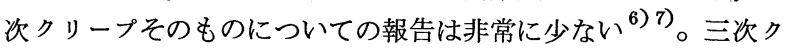
リープは, 破壊現象と密接に関連を持つものと考えられ, その解

* 1988 年 8 月 9 日受付 10 月 5 日受理 昭和 63 年度日本鉣業会春 季大会にて一部発表

1. 正会員 東京大学大学院 工学部資源開発工学科

2. 正会員 工博 東京大学助教授 工学部資源開発工学科

3. 正会員 工博 東京大学教授 工学部資源開発工学科
明はトンネル等の地下構造物の破壊の予知あるいは防止に役立つ ものと思われる。また, 応力一歪線図上での強度破壊点以降の特 性とも関連していると考元られ，時間依存性を考慮した構成方程 式の構築にも役立つものと思われる。既報 ${ }^{7)}$ では, 三城目安山岩 および河津凝灰岩を用いて, クリープ試験を行ない, 三次クリー プにおいて, 霆速度と残存寿命との間に簡単な法則があることを 示した。この法則が多くの岩種において成り立つとすると，岩盤 構造物の破壊の予知等に応用することが可能となる。よって本論 文においては，4 種類の試料を用いたクリープ試験を行ない, 三 城目安山岩および河津凝死岩について既報で得られた知見が今回 用いた試料に対しても成り立つかどうかを慎重に検討した。また， 試料の種類による違い等についても検討したので, ここに報告す る。

\section{2. 実験装置と試料岩石}

\section{$2 \cdot 1$ 実験装置および実験方法}

稲田花こう岩以外については，既報で報告したクリープ試験機 を用いた。試験片には，1 $\mathrm{s}$ 以内に所定の応力が加わるようにな っている。詳しくは，既報 ${ }^{7)}$ を参照されたい。

稲田花こう岩については, クリープ試験機の定格以上の荷重を 加える必要があったので, 最近当研究室で開発したデジタル制御 


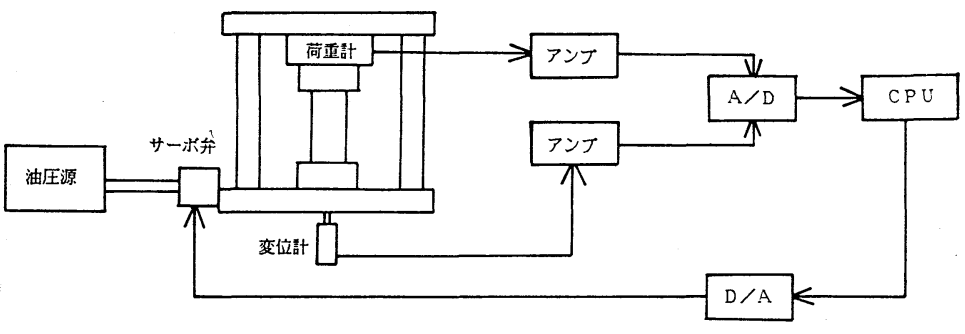

図 1 サーボ試験機の概念図

方式のサーボ試験機を用いた。デジタル制御方式にした理由は， 例えば変位速度一定試験からクリープ試験に変更するような, 制 御変数の変更を実験の途中で比較的簡単に行なえるためである。 図 1 にサーボ試験機の概略図を示す。油圧源は, 定格 $20 \mathrm{MPa}$ のも ので, サーボ弁に圧力を供給している。荷重は, ロードセル（日 本特殊測器製 $\mathrm{LRX}-10 \mathrm{~T}$ ) で測定し, その出力は直流増幅器 ( ユ ニパルス製 $\mathrm{AM} 30$ )を経て, $\mathrm{A} / \mathrm{D}$ 変換器に送られる。雑音防止の ため, 直流増幅器に内蔵の $1 \mathrm{kHz}$ のローパスフィルタをかけた。 変位は, 差動变圧器式変位計 (新光電機製 6014 ) で測定し, そ の出力は増幅器 ( 新光電機製 1533 ) を経て, A/D変換器に送ら れる。雑音防止のため, $4 \mathrm{kHz}$ のローパスフィルタをかけた。 $\mathrm{A} / \mathrm{D}$ 変換器 (システムポート筑波製 SPIF-AD 1) は, 12 bit の分解能をもち，1 チャンネル当りの変換時間は $20 \mu \mathrm{s}$ である。 D/A 変換器 (CONTEC製 DA 12-4) は, 12 bit の分解能で, セ トリング時間は $600 \mathrm{~ns}$ である。 $\mathrm{A} / \mathrm{D}$ 変換器と $\mathrm{D} / \mathrm{A}$ 変換器は, マ イクロコンピュータ（NEC製 PC-9801E）に組み込んである。 制御は, 比例制御によって行なった。デジタル制御方式では, 信 号は一定間隔 (サンプリング時間 ) ごとにサンプルされ, その後 ホールドされる。サンプリング時間が長いと制御性が劣化するが, 今回の実験で用いたサーボ試験機のサンプリング時間は $0.2 \mathrm{~ms}$ 程 度であり，この值がサーボ弁の時定数に比べてはるかに小さいこ とから, サンプリング時間の影響はほとんどないと考えられる ${ }^{8)}$ 。

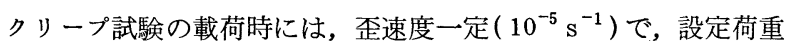
まで載荷を行ない, その後, 荷重を一定としてクリープ試験を行 なった。

変位の計測は $70 \mathrm{~ms}$ 毎に行なった。測定期間が長期にわたるの で，すべてのデータを記憶することは現実的に不可能である。幸 いクリープ試験では変位が単調に増加していくので, $\mathrm{A} / \mathrm{D}$ 変換器 の出力が指定された值を取った最終時間を順次記憶することにし た。この際重要になるのは, 二次クリープ領域のように歪速度が 小さくなる所での測定系の安定性であるが，今回の実験装置では， 変動が $\mathrm{A} / \mathrm{D}$ 変換器の分解能, 寸なわち歪に換算して $10^{-5}$ 程度で あり, 問題とならなかった。

\section{$2 \cdot 2$ 試料}

試料としては, 多胡砂岩, セメントモルタル, 中粒秋芳大理石 および稲田花こう岩を用いた。セメントモルタルは,ロックボルト用 のケー・エフ・シー製ドライモルタルを使用し, セメント: 砂 : 水 $=1: 0.5: 0.5$ の混合比で調製したものを用いた。セメントモル

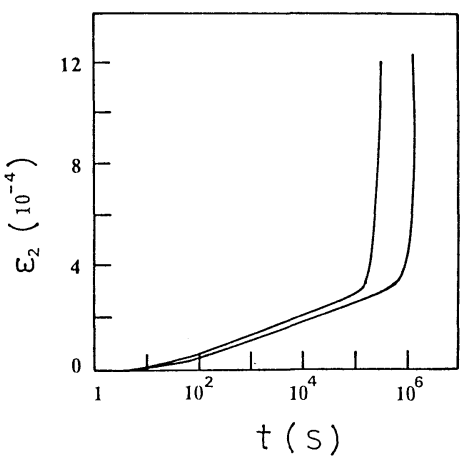

図 2 稲田花こう岩のクリープ歪 の経時変化

タルは, 製作後しばらくの期間力学的特性が変化しやすいので, 製作してから $3 \sim 4$ 年経たものを用いた。試験片としては, 直径 $2.4 \mathrm{~cm}$, 高さ $5.2 \mathrm{~cm}$ の円柱形に整形したものを用いた。試験片の 両端面は, 平面研削盤により, 平行度士 $0.02 \mathrm{~mm}$ 以内に仕上げた。 試験片は, 整形後 1 力月以上自然乾燥させてから使用した。試料 の物性值, クリープ応力およびクリープ寿命を表 1 に示す。

\section{3. クリープ実験結果}

\section{$3 \cdot 1$ 一次クリープ領域における歪, 歪速度の経時変化}

図 2 は, 載荷後 $1 \mathrm{~s}$ での值を原点とした稲田花こう岩のクリー プ歪 $\varepsilon_{2}$ の経時変化を片対数グラフ上に示したものである。図より， クリープ歪は約 $50 \mathrm{~s}$ 経過した後直線的に増加してゆき，その後急 速に傾きを增して最終的な破壊に至っているのがわかる。これよ り, 一次クリープ領域では, クリープ歪が経過時間の対数に比例 するという対数クリープ則が成り立っていることがわかる。この ことは, 他の試料でも成り立っている。よって, 一次クリープ領 域においては載荷後 $1 \mathrm{~s}$ での值を原点としたクリープ歪と経過時 間 $t(\mathrm{~s})$ との間には次式のような関係があることがわかる。

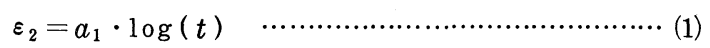

直線部分において求めた(1)式の $a_{1}$ の值を表 2 に示す。表 2 のう ち三城目安山岩と河津凝灰岩についての数值は既報の実験結果 ${ }^{7)}$ より求めた。稲田花こう岩, 秋芳大理石, 多胡砂岩に比べて, セ メントモルタル, 三城目安山岩, 河津凝灰岩では(1)式の傾き $a_{1}$ が大きな值となっていることがわかる。

図 3 に稲田花こう岩について得られたクリープ歪速度 $\dot{\varepsilon}_{2}\left(\mathrm{~s}^{-1}\right)$ と経過時間 $t(\mathrm{~s})$ の関係を両対数グラフに示す。図において, ク リープ歪速度 - 時間曲線は, 約 $50 \mathrm{~s}$ 経過した後ほぼ - 1 の傾きを 持っているが，次第に傾きが水平に近付き，その後急激に増加し ているのがわかる。載荷後 $10 \mathrm{~s}$ 経過した時の歪速度は, 稲田花こ う岩以外の試料では, 既報 ${ }^{7)}$ に示したとおり,ほぼ $10^{-5} \mathrm{~s}^{-1}$ 程度で あったが, 稲田花こう岩では, $10^{-6} \mathrm{~s}^{-1}$ 程度であった。稲田花こ う岩以外では $1 \mathrm{~s}$ 以内に設定荷重まで載荷を行なっているが, 稲 田花こう岩では, サーボ試験機を用いて定歪速度で約 700 s かけて 載荷したため, 初期の歪速度が小さくなったものと思われる。

表 1 試料の物性值及びクリープ応力・寿命

\begin{tabular}{l|c|c|c|c|c|c|c|c}
\hline & $\begin{array}{c}\text { 圧縮強度* } \\
(\mathrm{MPa})\end{array}$ & $\begin{array}{c}\text { ヤング率* } \\
(\mathrm{GPa})\end{array}$ & $\begin{array}{c}\text { 圧裂引張強度 } \\
(\mathrm{MPa})\end{array}$ & 見掛け比重 & $\begin{array}{c}\text { クリープ応力 } \\
(\mathrm{MPa})\end{array}$ & $\begin{array}{c}\text { 幾何平均寿命 } \\
(\mathrm{s})\end{array}$ & $\begin{array}{c}\text { 算術平均寿命 } \\
(\mathrm{s})\end{array}$ & $\begin{array}{c}\text { クリープ } \\
\text { 試験個数 }\end{array}$ \\
\hline 稲田花こう岩 & 169 & 24.0 & 11.3 & 2.61 & 155 & $3.6 \cdot 10^{4}$ & $3.3 \cdot 10^{5}$ & 6 \\
多 胡 砂 岩 & 32.5 & 8.13 & 4.34 & 2.08 & 31.0 & $7.0 \cdot 10^{3}$ & $9.2 \cdot 10^{3}$ & 4 \\
セメントモルタル & 71.5 & 14.3 & 5.27 & 2.09 & 64.0 & $1.1 \cdot 10^{5}$ & $1.0 \cdot 10^{6}$ & 12 \\
中粒秋芳大理石 & 57.8 & 27.2 & 5.29 & 2.60 & 53.8 & $4.7 \cdot 10^{3}$ & $1.1 \cdot 10^{6}$ & 10 \\
\hline
\end{tabular}

* 定歪速度 $10^{-5} \mathrm{~s}^{-1}$ での一軸圧縮試験による。 
表 2 クリープ試験結果より求めた諸值

\begin{tabular}{c|c|c|c|c|c}
\hline & $\begin{array}{c}(1) \text { 式の } a_{1} \\
\left(10^{-4}\right)\end{array}$ & $\begin{array}{c}(3) \text { 式の } a_{2} \\
\left(10^{-4}\right)\end{array}$ & $\begin{array}{c}\text { (4)式の } b_{3} \\
\text { 最小歪速度となった時のクリープ歪 }\end{array}$ & $\begin{array}{c}(6) \text { 式の } n^{*} \\
\left(10^{-6}\right)\end{array}$ \\
\hline 稲田花こう岩 & 0.7 & 1.4 & -4.2 & $300 \sim 400$ & 51 \\
多 胡 砂 岩 & 1.0 & 1.0 & -4.4 & $300 \sim 400$ & 72 \\
セメントモルタル & 2.3 & 0.6 & -4.6 & $2300 \sim 4000$ & 24 \\
中粒秋芳大理石 & 0.4 & 0.4 & -4.7 & $300 \sim 400$ & 64 \\
河 津 凝 灰 岩 & 1.7 & 1.3 & -4.2 & $500 \sim 900$ & 58 \\
三城目 安山岩 & 2.4 & 2.4 & -4.0 & $900 \sim 1100$ & 35 \\
\hline
\end{tabular}

* 多胡砂岩, セメントモルタルは, 文献 13) より, 他は文献 12) より引用。

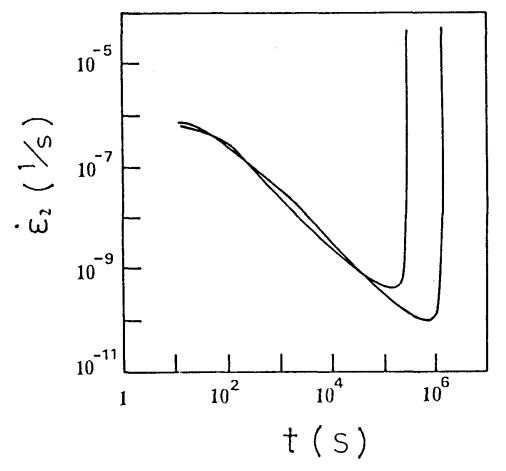

図 3 稲田花こう岩のクリープ歪 速度の経時变化

\section{$3 \cdot 2$ 三次クリープ領域における歪, 歪速度の経時変化}

図 2，3のように，経時変化の対数を横軸に取ったのでは, 三 次クリープ領域での昰の変化を詳しく議論し難いので, 残存寿命 $T$ という概念を導入した ${ }^{7)}$ 。

$$
T=t_{F}-t
$$

ただし， $t_{F}$ は破壊寿命， $t$ は試験開始時よりの経過時間である。 この残存寿命の対数を横軸に取り, 各試料の実験結果を表したの が, 図 4, 5 である。図 4 より, 多胡砂岩, セメントモルタル, 秋芳大理石では, 残存寿命が小さくなった時すなわち破壊に近付

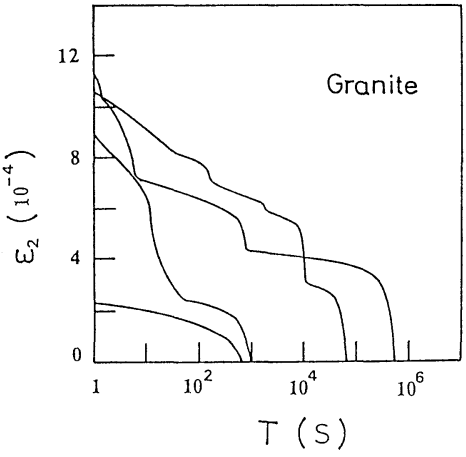

(a) 稲田花こう岩

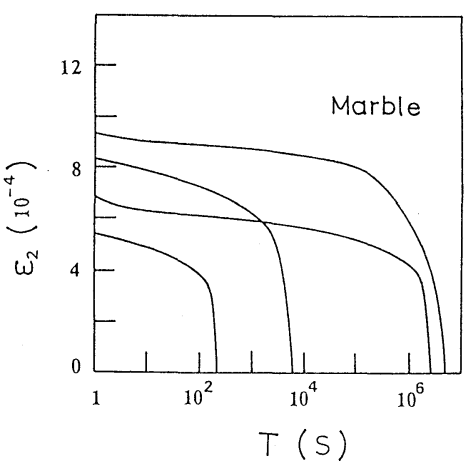

(d) 秋芳大理石

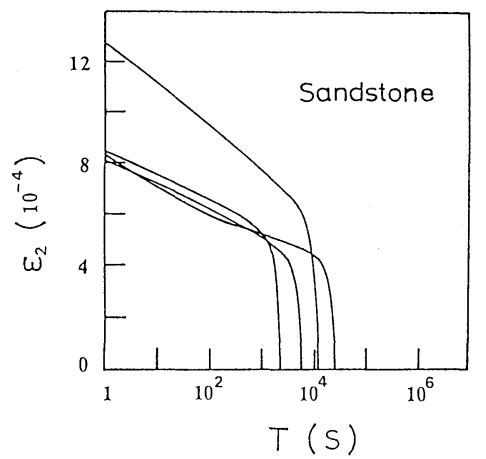

(b) 多胡砂岩

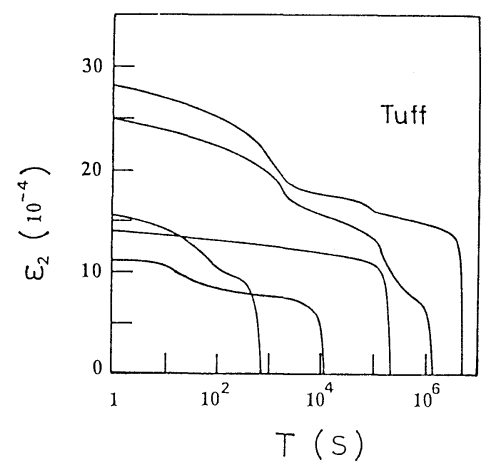

(e) 河津凝灰岩

くとクリープ歪と対数表示による残存寿命との間に直線関係が見 られ，次式で示されるような実験式が成り立っていることがわか る。

$$
\varepsilon_{2}=a_{2} \cdot \log (T)+b_{2}
$$

直線部分において求めた(3)式の $a_{2}$ の值を表 2 に示す。稲田花こ う岩と河津凝灰岩では, クリープ歪一残存寿命曲線はかなり複雑 に曲がりくねっているが，これを直線近似して(3)式に当てはめて 求めた $a_{2}$ も表 2 に示した。表 2 より, 秋芳大理石, セメントモル タルでは $a_{2}$ の値が小さく, 三城目安山岩, 河津凝灰岩では $a_{2}$ の 值が大きくなっているが目立つ。また表 2 より, セメントモルタ ルについては, 一次クリープにおける傾きの方が, 三次クリープ の傾きの 4 倍程度になっているが, 他の試料では, ほぼ同じ值と なっていることがわかる。セメントモルタルを除き,一次クリー プにおける歪の経時変化と, 三次クリープにおける歪の残存寿命 による変化が，定性的にはもちろん定量的にも，ほぼ同じになっ ている。

図 5 より，残存寿命が小さくなるに従い，すなわち破壊に近付 くと, 歪速度が次第に増加しているのがわかる。しかも図より, 寿命の大小に拘わらず残存寿命の小さい領域すなわち破壊間近で は, 残存寿命と歪速度の間には, 両対数グラフ上でほぼ直線関係 が見られる。このことは，(3)式を時間で微分することによっても 得られ, 式の形で表すと以下のようになる。

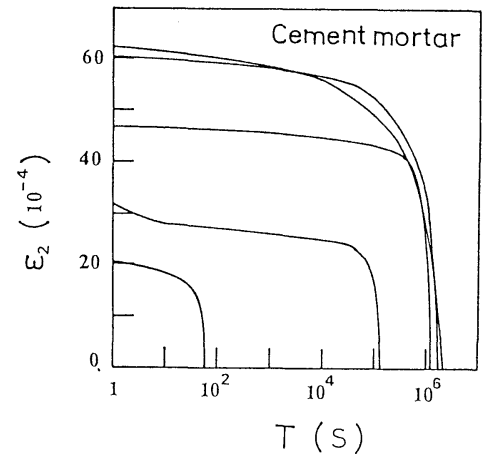

(c) セメントモルタル

図 4 クリープ歪と残存寿命 との関係 


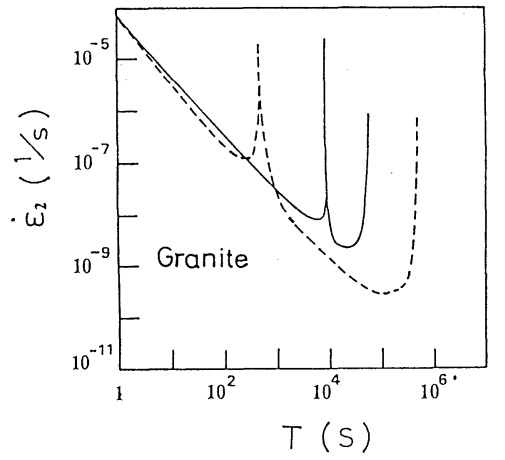

(a) 稲田花こう岩

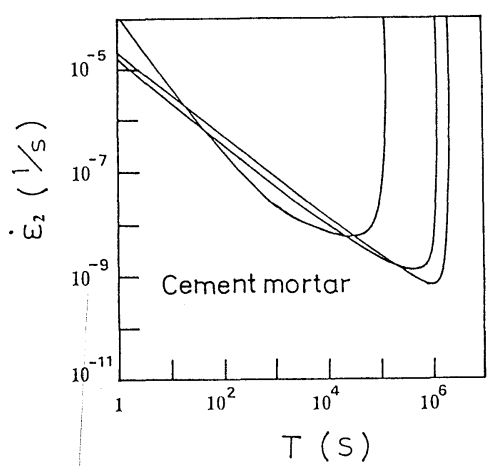

(c) セメントモルタル

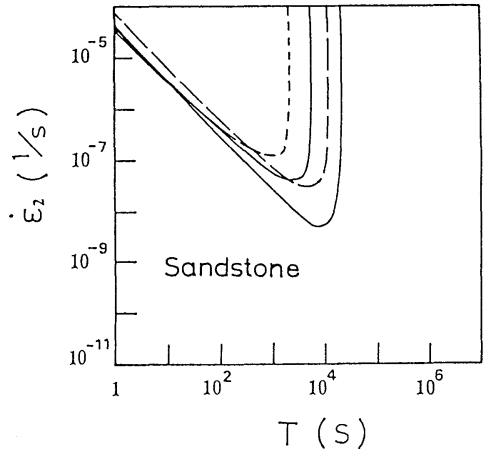

(b) 多胡砂岩

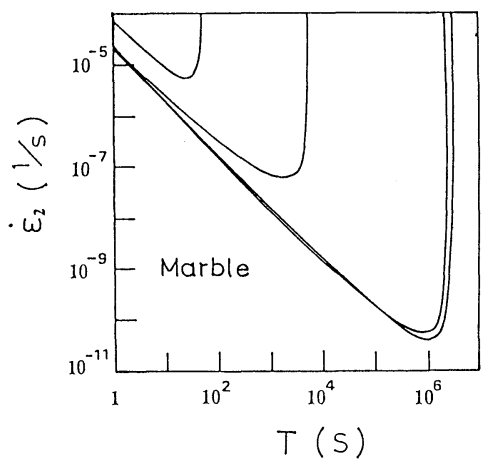

(d) 秋芳大理石

図 5 クリープ䨤速度と残存寿命との関係

$\log \left(\dot{\varepsilon}_{2}\right)=-\log (T)+b_{3}$ ただし，

$$
b_{3}=\log \left(a_{2} \cdot \log (e)\right)
$$

である。ここで， $e$ は自然対数の底である。(4)式における $b_{3}$ の 值を表 2 に示す。(3)，(4)式は，既報で報告した三城目安山岩，河 津凝灰岩についても成り立っており ${ }^{7)}$ ，かなり一般的に成り立つ

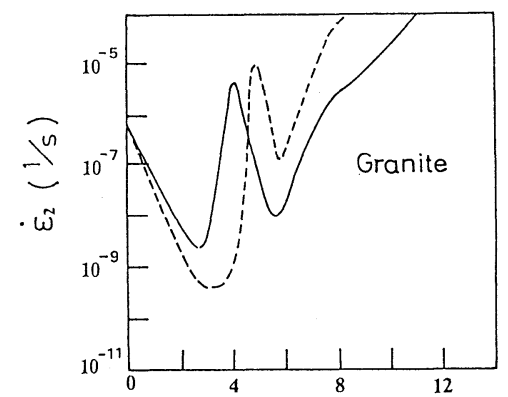

$\varepsilon_{2}\left(10^{-4}\right)$

(a) 稲田花こう岩

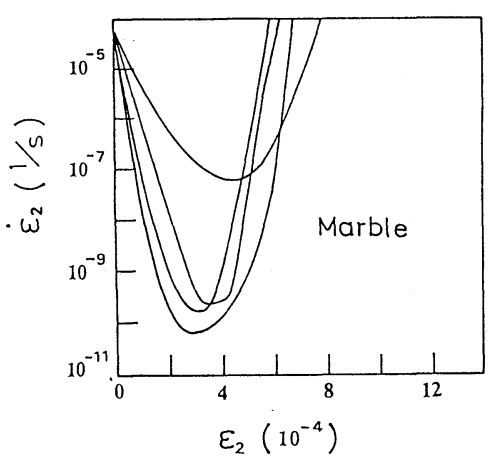

(d) 秋芳大理石

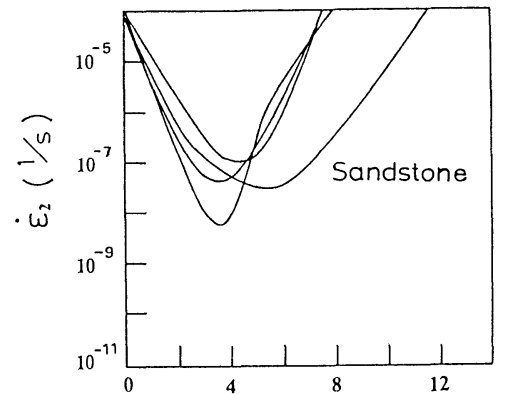

$\varepsilon_{2}\left(10^{-4}\right)$

(b) 多胡砂岩

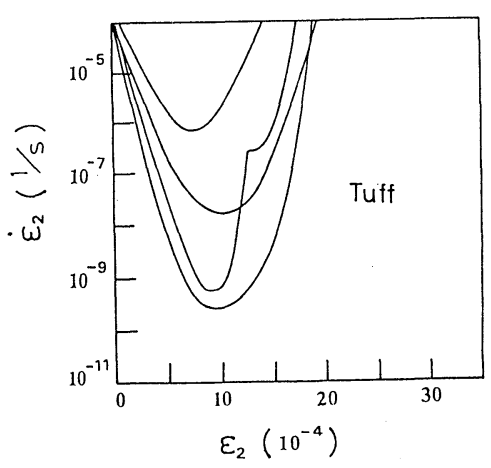

(e) 河津凝灰岩 ほぼ対称とな ける応力ー歪線図とクリープ歪との関係を表すため, クリープ歪 速度が最小となる応力と歪の值を図 $7 に$ に三角形で示す。ただし, 図 7 に示した応力一丕線図は，応力㷌還制御 ${ }^{9)}$ を用い，載荷速度 $10^{-5} \mathrm{~s}^{-1}$ によって得られたものである。眓より, 三城目安山岩,

になる。

$$
T=a_{2} \cdot \log (e) / \dot{\varepsilon}_{2}
$$

$a_{2}$ がわかっていれば, 歪速度を測定するこ とにより，(5)式を用いて，残存寿命を推定 することができる。実際の岩盤の計測にお いて, 歪の絶対量を測定することは, 困難 であるが，歪速度なら比較的容易に測定す ることができると思われる。(5)式のような 関係が一般に成り立つとすれば，歪速度が 加速的に増加している状態において，歪速 度だけで, 最終破壊までの時間の予知がで きることになる。

\section{$3 \cdot 3$ クリープ歪と歪速度の関係}

図6にクリープ歪と歪速度の関係を片対 数グラフ上に示す。図より, はじめクリー プ歪が増加するに従い，歪速度が減少して ゆき，ある所で最小となり，その後徐々に 増加しているのがわかる。最小歪速度とな った時のクリープ昰を表 2 に示す。表より， 実験の範囲では, $3 \cdot 10^{-4} \sim 4 \cdot 10^{-3}$ 程度の クリープ歪になると, 歪速度が減少より増 加に転じているのがわかる。図6より，三 城目安山岩, 秋芳大理石, 多胡砂岩, 河津

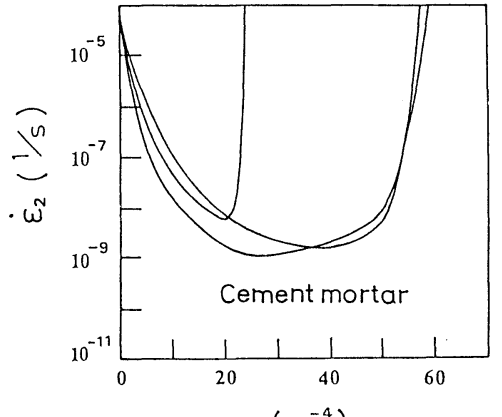

$\varepsilon_{2}\left(10^{-4}\right)$

(c) セメントモルタル

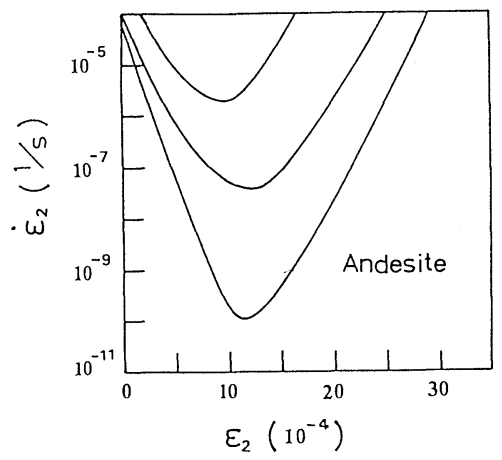

(f) 三城目安山岩

図6クリープ雪速度とクリープ雨との関係 


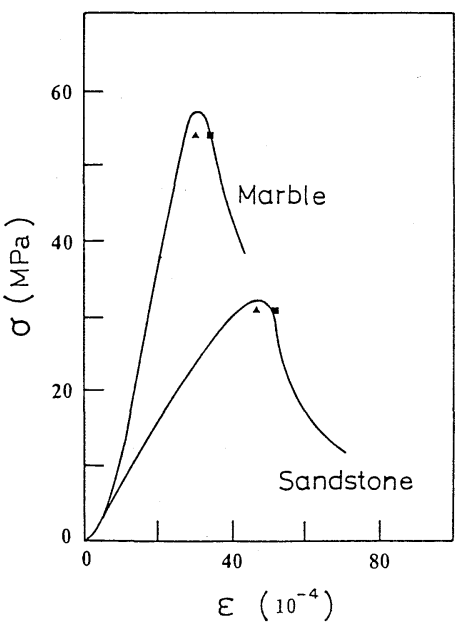

(a) 秋芳大理石, 多胡砂岩

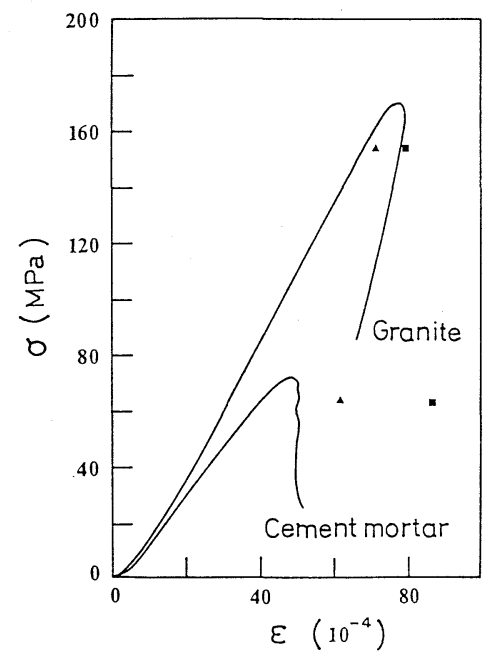

(b) 稲田花こう岩, セメントモルタル

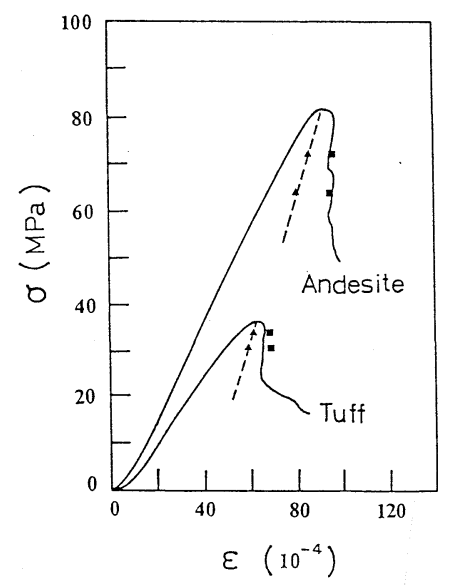

(c) 三城目安山岩, 河津凝灰岩 三角形は最小クリープ歪速度の時の応力と歪の值, 四角形は残存寿命が $1 \mathrm{~s}$ の時 の応力と歪の值を表す。(c)の破線は強度破壊点からの除荷曲線を表す。

\section{図7応力 - 歪線 図}

秋芳大理石, 河津凝灰岩および多胡砂岩は強度破壊点以前, 以降 の応力ー歪曲線のほぼ中間に歪速度が最小となる所が存在してい ることがわかる。稲田花こう岩は, 応力ー歪曲線の内側に存在す るが多少強度破壊点以前の曲線に近付いた所に位置しているのが わかる。一方，セメントモルタルでは応力ー歪曲線内ではなく， 強度破壊点以降の曲線の外側に存在しクリープ歪がかなり大き くなっていることがわかる。三城目安山岩, 河津凝灰岩について は，2つのクリープ応力で実験を行なっている。図7(c)に示すよ うに, 歪速度が最小となる点は, 破線で示した強度破壊点から除 荷した線の上に並ぶ。除荷中の非弾性歪の変化は小さいので, こ のことは, 強度破壊点における非弾性歪とクリープ試験における 最小歪速度となった時の非弾性歪が同じ值であることを示してい る。換言すれば, 応力の大きさに関係なくある量の非弾性歪が岩 石内に蓄積すると, その後は加速的に変形していくことになる。

破壊直前, すなわち破壊の $1 \mathrm{~s}$ 前における応力, 歪の位置を小 四角形で図 7 に示した。図より, 三城目安山岩, 河津凝死岩, 秋 芳大理石, 多胡砂岩では, ほぼ強度破壊点以降の応力-歪曲線上 に存在していることがわかる。稲田花こう岩では, 多少応力ー歪 曲線の外側に位置しており, セメントモルタルは, かなり外側に 位置している。

\section{$3 \cdot 4$ 各岩石における特幑}

表 2 よりわかるように, 稲田花こう岩では, 一次クリープ領域 での傾き $a_{1}$ より, 三次クリープ領域での傾き $a_{2}$ の方が大きくな

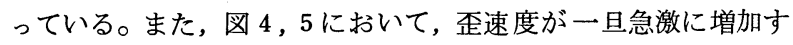
る所が存在している。この歪速度が極大となる時刻を基準時刻 $T_{s}$ とし，この基準時刻までの時間 $\left(T_{s}-t\right)$ と歪速度を両対数グラフ に示した例が図 8である。図より，基準時刻に近付くにつれて， 歪速度が次第に大きくなり三次クリープ領域と同様の傾向を示す ことがわかる。また, 基準時刻からの経過時間 $\left(t-T_{s}\right)$ を横軸と して整理したのが図9である。図より, 基準時刻以降しばらくの 間, 一次クリープ領域と同様に対数クリープ則に従った变形の起 こっていることがわかる。花こう岩では, 試験片の側面が俆々に 剥離していく。このような側面での局部破壊が積み重なって最終 的に有効断面積が減少し破壊する。よって, 図 8,9 のような歪速 度 - 時間曲線が得られたのは, 試験片の側面より岩石片が剥離し たことが原因であると考えられる。稲田花こう岩では, 図 8,9
に挙げた例以外にも，同様の傾向がしばしば現れた。このような 現象が起こる原因について考えてみる。まず，側面が破壊し有効 断面積が減少すると，まだ破壊していない領域での応力が増加し， その結果弾性歪も増加するであろう。しかし測定上は，この弾性 歪もクリープ歪に含まれてしまう。その結果, 一次クリープ領域 での傾き $a_{1}$ に比べて, 三次クリープ領域での傾き $a_{2}$ の方が見掛 け上大きくなったのであろう。

多胡砂岩は, 図 7 (a) よりわかるように, 強度破壊点以降, 応力 一歪線図が負の傾きを持つクラス I 岩石に分類され，一軸圧縮試 験を行なうと強度破壊点以降徐々にせん断面が形成される。よっ

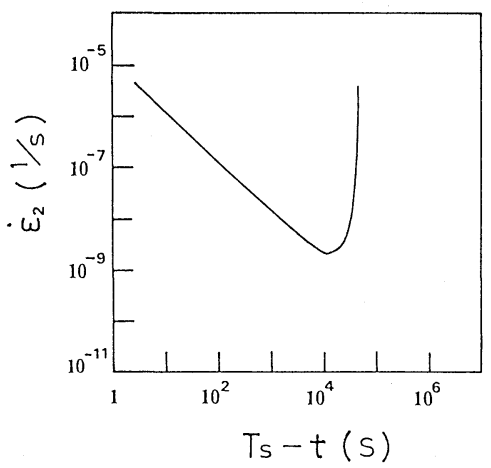

図8 稲田花こう岩のクリープ霆速度と基 準時刻までの時間との関係

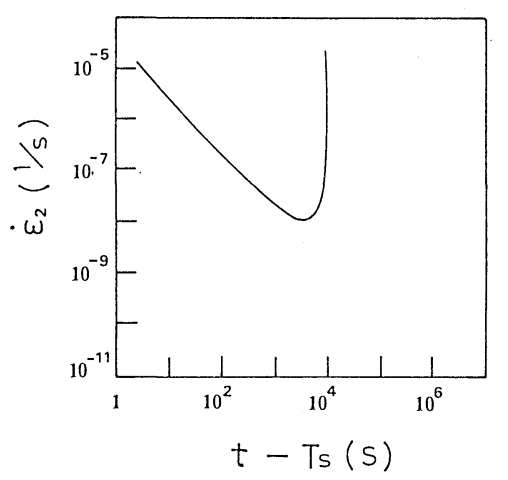

図9 稲田花こう岩のクリープ霆速度と基 準時刻からの時間との関係 
て, 三次クリープにおいても徐々にせん断面が形成されてゆき, 図 4 (b)のように滑らかなクリープ曲線が得られたものと思われる。 一方, 河津凝灰岩の一軸圧縮試験を行なうと, 強度破壊点以降, 数回にわたりせん断面が急激に形成されることが観察される。よ って, 三次クリープ領域においても同様に，せん断面の形成が急 激に起こり, 図 $4(\mathrm{e})$ のようにクリープ歪一残存寿命曲線が歪曲す るのではないかと考えられる。

セメントモルタル以外の試料では, 歪速度が一定となる二次ク リープ領域が明瞭に現れなかった。他方, 図 6(c)からもわかるよ うにセメントモルタルでは, かなり明瞭に二次クリープと呼ばれ ている歪速度がほぼ一定になる領域が現れることが多く, その歪 速度は $10^{-9} \mathrm{~s}^{-1}$ 程度であった。また, 図 7 (b)に示したように, ク リープ歪がかなり大きく, 歪速度が最小となる点が, 応力ー歪線 図内に含まれない点でも, 他の試料と異なる傾向を示した。セメ ントモルタルの二次クリープ領域で卓越している現象としては, 応力腐食に基づくクラックの進展が挙げられる。クリープ試験で は応力が一定であるので, クラック先端部の反応物の濃度が一定 であれば, 応力腐食に基づく丕速度はほぼ一定となり ${ }^{10)}$, 二次ク リープ現象を説明することができる。ただし，応力腐食が起きて いるかどうかは，今回の実験では判断できない。

\section{4. 考察とまとめ}

各試料についてそれぞれ 1つのクリープ応力で実験を行なった。 しかし破壊寿命のばらつきは, 非常に大きいのが, 図4よりわか る。この理由として, 試験片の強度のばらつきが考えられる。通 常, クリープ応力と破壊寿命 $t_{F}$ の間に以下の式が成り立つとさ れている ${ }^{11)}$

$$
t_{F}=a \cdot\left(\sigma_{c} / \sigma_{c r}\right)^{n+1}
$$

ただし, $\sigma_{c r}$ はクリープ応力, $\sigma_{c}$ は破買応力, $a, n$ は岩石によ る定数である。一軸圧縮試験に扔ける破壊強度の載荷速度依存性 より求めた $n$ を表 2 に示す $\left.{ }^{12)} 13\right)$ 。今回行なったクリープ試験にお いて, 設定した応力は一定であったが, 試験片ごとの破壊応力が ある程度ばらついていたと考えられる。表 2 よりわかるように， $n$ の值はかなり大きく, (6)式より計算される破壊寿命がかなりば らつくことになる。よって, 今回行なった実験においても, 破壊 寿命が 5 桁程度もばらついたのではないかと考えられる。

本論文において 4 種類, 既報 ${ }^{7)}$ で 2 種類の岩石を用いて, クリ ープ試験を行なった結果をまとめると次のようになる。一次クリ 一プ領域においては，ほぼ対数クリープ則が成り立つ。三次クリ ープ領域では寿命, 岩種に関係なく残存寿命と歪速度は両対数グ ラフ上で傾きがほぼ - 1 の直線となり, かつ残存寿命が $1 \mathrm{~s}$ の時, 歪速度が $2 \cdot 10^{-5} \sim 10^{-4} \mathrm{~s}^{-1}$ であった。また, (5)式を利用して, 歪
速度より破壊までの時間を計算できることがわかった。この結果 が実際の岩盤に成り立つとすれば，岩盤構造物の破壊予知を行な いうることになる。しかし, 実際の岩盤では, 応力状態, 含水率, 温度等の条件が複雑に絡みあっており, これらの条件下において も, 今回得られた結果が成り立つかどうかを今後調べていく必要 がある。

本研究では, 従来より使用してきたクリープ試験機を用いた他, サーボ試験機をも併用してクリープ試験を行なった。サーボ試験 機は岩石力学の分野において，かなり普及してきており，クリー プ試験にも比較的簡単に用いることができるようになっている。 しかしながら，三次クリープ領域のように，变位速度が加速的に 増加していく領域においては, 試験機の応答速度が追いつかず, 設定した荷重に比べて実際の荷重が低下している可能性がある。 今回の稲田花こう岩のクリープ試験においては, 残存寿命が $1 \mathrm{~s}$ までは応力が設定値を保っていたので，そこまでのデータを示し た。しかし，もっと残存寿命が小さい所までのデータが望まれる ので, そのためにはサーボ試験機の特性を考慮して得られたデー タの信頼性についても十分に検討しておく必要がある。

\section{参考 文 献}

1) Parsons, C.R.\& Hedley, D. G. : Int. J. Rock Mech. Min. Sci., 3, p. 325 335 (1966)

2) Kranz, R. L. \& Scholz, C.H. : J. Geoph. Res., $82[30]$, p. 4893 4898 (1977)

3) Wawersik, W. R. : Proc. 14 th U.S. Symp. Rock Mech., p. 85 106, The Pennsylvania State Univ., Pennsylvania (1972)

4) Scholz, C. H. : J. Geoph. Res., 73[10], p. 3295 3302 (1968)

5) Cruden, D. M. : Int. J. Rock Mech. Min. Sci. \& Geomech. Abstr., 11, p. 67 73 (1974)

6）磯部俊郎・冨長勇作・Hardy Jr., H. R. 平松雅宏 : 日本鉱業会 研究会. 業續発表講演会講演要旨集 (昭和 56 年度春期大会 ), $p$. 29 30 (1981)

7) 大久保誠介・西松裕一：日釷誌，102[1181]，p. 395 400 (1986)

8）大久保誠介 $\cdot$ 福井勝則 $\cdot$ 西松裕一：日鉱誌, $104[1200], p .63$ $\sim 67$ (1988)

9）大久保誠介・西松裕一：日鉱誌, $100[1161], p .1052 \sim 1056$ (1984)

10) Orson L. Anderson and Priscilla C. Grew: Review of Geophysics and Space Physics, 15, p. 77 104 (1977)

11) B. J.S.Wilkins: Int. J. Rock Mech. Min. Sci.\& Geomech. Abstr., 24, p. 379 380 (1987)

12）大久保誠介・何昌栄・西松裕一：日鉱誌，103[1189]，p.177〜 181 (1987)

13）福井勝則：東京大学修士論文, p. 52 54 (1987) 